\title{
Ben Jonson's Politics
}

\author{
JOSEPH JOHN KELLY
}

In 1928, J.W. Allen, in his standard history of sixteenth-century political thought, wrote, "I cannot find anything that ought to be called a theory of the divine right of Kings in Elizabethan writings. I do not find it even in the writings of King James, which seem to me to express no theory at all." Referring to divine right as a "hackneyed phrase," Allen wrote that there was "no full expression of it earlier than the writings of Robert Filmer," and "His view was certainly not that of the mass of the royalist writers of the period of the Civil War." In 1978, Leah S. Marcus, writing in ELH, confidently asserted that Ben Jonson's Vision of Delight "reaffirms the mystery of divine right." 2 In her view of Jonson's politics Marcus follows Herford and Simpson, Talbert, Enck, and Meagher, and allies herself with the many critics who think that Jonson could conceive of government only as a paternalistic monarchy. ${ }^{3}$ Can there be a fifty-year gap between the history of political thought and literary history? It seems that literary critics suffer from the outdated conception that G.R. Elton analyzes:

Since Figgis's day ... it has been difficult to free the sixteenth and seventeenth century from an air of being exclusively peopled by divinely entitled and therefore absolutist kings. Theories of kingship which stressed the rights of subjects and the dominance of law have tended to be overlooked in the dazzling light of God-granted authority. ${ }^{4}$

The situation in the study of Jonson's politics today is similar to the Tillyard-Campbell-Ribner-Reese period in the study of Shakespeare's history plays. Unless we achieve the same sophistication in the interpretation of Jonson's political ideas that Shakespeare critics have achieved in interpreting Shakespeare's, we will remain trapped in a simplistic "Elizabethan World Picture," a pseudo-historical stereotype. Lacking real knowledge of the political and historical background to sixteenth- and seventeenth-century literature, we continue to assert that Jonson believed in divine right - to grossly simplify Jonson and to ignore the central monarchist tradition in the England of his time. 
By examining Jonson's relationship to contemporary political thought, we shall see the political concomitant of Jonson's characteristic independence and critical attitude. The sources of Jonson's ideas, which may be divided into humanism, English political theory and constitutional thought, the classics, Machiavelli, the English popular tradition, and Catholicism, indicate that Jonson was a constitutional monarchist - a position that was at once conservative and potentially revolutionary in being the traditional English view opposed to the view of the Stuart monarchs. In the complex mainstream of political thought in his time, identifiable neither as a conservative nor a revolutionary, Jonson shared the ambivalence of his countrymen, who, a few years after his death, engaged in civil war. The special significance of Jonson's ambivalence is that it shows that the Stuart position in England was undermined even by its purported spokesmen. The most striking fact that emerges from the following pages is that Jonson's politics, the politics of James's principal masque-writer, were closer to the Parliamentary opposition's than to the Court's.

The very fact that Jonson was concerned with political, social, and economic issues is in itself evidence of his participation in the English humanist tradition, linking him to early sixteenth-century writers on the Christian commonwealth like Erasmus and More. ${ }^{5}$ Jonson's attack on a society ruled by "clothes" and money rather than by conscience and merit recalls works like Adagia, The Praise of Folly, and Utopia. When Jonson writes in Discoveries that "the excesse of Feasts, and apparell, are the notes of a sick State," he echoes sentiments like More's; his attack on the false riches of money recalls the famous visit of the Anemolian ambassadors to Utopia:

Money never made any man rich, but his mind. He that can order him selfe to the Law of nature, is not onely without the sense, but the fear of poverty. $\mathrm{O}$ ! but to strike blinde the people with our wealth, and pompe, is the thing! what a wretchednesse is this, to thrust all our riches outward, and be beggars within: to contemplate nothing, but the little, vile, and sordid things of the world; not the great, noble, and pretious? ${ }^{6}$

In addition to Jonson's general interest in social problems and his disdain for the pursuit and display of wealth, his attitude toward the nobles also shows his similarity to the humanists. Both the humanists' emphasis on their own responsibilities as counsellors to the nobles and their insistence that nobles serve the public good are reflected in Jonson's work. ${ }^{7}$ Jonson's stress on the need for humanists to counsel rulers, implicit in his masques and poems, is expressed in Discoveries, where he writes that "Learning needs rest: Soveraignty gives it. Soveraignty needs counsell: Learning affords it" (VIII, 565). For Jonson, schools are "the Seminaries of the State" (VIII, 592); to him, "a Prince without Letters is a Pilot without eyes," in need of books, which are "the best Counsellors" (VIII, 601). Jonson's hatred of flatterers is largely 


\section{4 / Renaissance and Reformation}

motivated by his insistence on the need for good counsellors for nobles and princes. The attacks on nobles' flatterers in Discoveries (VIII, 601, 612-13), as well as his articulation of the concept of laudando praecipere, of flattery as the "Pick-lock of tender eares" (VIII, 565-6, 596), show his humanistic emphasis on the counsellors' importance to the commonwelth. In a passage which derives from both Lipsius and Montaigne, Jonson writes:

They say Princes learne no Art truly, but the art of Horse-manship. The reason is, the brave beast is no flatterer. He will throw a Prince, as soone, as his Groome. Which is an Argument that the good Counsellors to Princes are the best intruments of a good Age. For though the Prince himselfe be of most prompt inclination to all vertue: Yet the best Pilots have need of Mariners, besides Sayles, Anchor, and other Tackle. (VIII, 601-02).

The humanists' demand that nobles serve the public good, their insistence that nobles have duties to the people they govern, is also expressed in Jonson's work. Jonson stresses the importance of "a common good" (VIII, 593) in Discoveries, writing that one should love a Prince "when he hath put on the care of the publike good, and common safety" (VIII, 594), and defining his ideal king in this way: "A good King is a publike Servant" (VIII, 601). These references, along with Catiline 2.363-406 and the epigrams on Pembroke and Neville (Ep. CII and CIX), establish that Jonson's primary loyalty was to the commonwealth, not to any particular part of it. If further evidence of Jonson's emphasis on public service is needed, one may cite Epigram XCV and the dedication to Every Man Out, in which Jonson shows rare humility about his art, confessing to Savile (albeit in a slight concession) that writing is less than doing (1.25), and telling the members of the Inns not to be distracted by his play from more important matters: "Yet, I command, it lye not in the way of your more noble, and usefull studies to the publike" (III, 421).

Another humanistic element in Jonson's social thought is the idea that "Vertue alone, is true Nobilitie," that degrees of birth and wealth are illusory distinctions. ${ }^{8}$ It is important to point out the tradition behind Jonson's egalitarian tendencies. Jonson's ridicule of nobles as no more than clothes dummies follows statements like this one in Utopia, which explodes the pretences of the nobility:

They wonder that anyone can be so mad as to think himelf more noble on account of the texture of a finer wool, since, however fine the texture is, a sheep once wore the wool and yet all the time was nothing more than a sheep. ${ }^{9}$

Jonson, in defending citizen learning against the nobles' snobbery in "A Speach according to Horace" (Und. XLIV), in identifying himself with Crites, in celebrating Cicero's virtue in Catiline, scorning the conspirators' gibes at the "new man" (3.19) and "petty fellow" (4.158), embodies the humanists' stress on worth over birth. 
This humanist influence may also be operating in Jonson's strident denunciations of the ignorance of both nobles and commoners alike. In placing merit over rank, the humanists defined merit largely in terms of a humanistic education, identifying ignorance as the source of all vice - an idea Jonson endorses in Discoveries: "I know no disease of the Soule, but Ignorance" (VIII, 588). ${ }^{10}$ Thus, the source of Jonson's egalitarian thought may have been a source of his intellectual elitism too, in that the humanists simultaneously championed worth over birth and scorned the people (for their ignorance) as much as they scorned the nobles: Jonson, who derided both popular and courtly taste, seems part of the tradition. His arrogance, directed at commoners and nobles alike, stems from the humanistic concept of merit. When Jonson decries popular chivalric romances in "An Execration" (Und. XLII, 11. 66-71), he continues, though not in a straitlaced way, the work of the arrogant Ascham.

Besides the debts to the humanists that we can trace in Jonson's social thought, there are other important ideas Jonson received from them. One very important idea, which emerges naturally from the humanists' stress on merit over rank and on the role of the counsellor, is the humanist tendency toward republicanism. ${ }^{11}$ Of the two humanist traditions discussed by Caspari, the Elyot and Spenser tradition, which stressed the rights of monarchs and the need for gentlemen to rule, and the More and Erasmus tradition, which drew from the classics the idea of a "mixed state," a balance of monarchical and popular elements centred in Parliament, Jonson seems closest to the latter, which re-emerged in the seventeenth century with the break-up of the Tudor settlement. The humanist influence may explain the number of passages in Jonson that show republican attitudes. These attitudes are evident in Discoveries, where, for example, he openly admits the possibility of an elective monarchy. Discussing the ways by which princes rise to office, he writes, "There is a great variation betweene him, that is rais'd to the Soveraignty, by the favour of his Peeres; and him that comes to it by suffrage of the people" (VIII, 598). There is no doubt that suffrage means election, for Jonson uses the word in his comment that "suffrages" in Parliament are numbered, not weighed (VIII, 579). At the end of the passge Jonson expresses his preference for election by the people over election by the nobles (VIII, 398-99).

Besides expressing this preference, Jonson, despite his distrust of popular ignorance, emphasizes that the prince's security is possible only in the people's love, stressing it in the passage just cited and in the Coronation Entertainment (11. 181-96). Furthermore, three times, in Epigram LXVII, in the Panegyre (11. 139-43), and in Catiline (3.11-13, 60-61, 120-24), he even alludes to the idea that vox populi vox dei. In the epigram, the "kings choice" ratifies the "peoples voice" to establish Suffolk's rise to honour as God's will. The Panegyre praises James for not seeking to be crowned "Before mens hearts had crown'd him" (1. 143). In Catiline, the popular 
election of the "new man" Cicero, to the great displeasure of the aristocratic rebels, has divine approbation: "The voice of Rome is the consent of Heaven" (3.61). Jonson's participation in the English humanist tradition of More and Starkey is certain.

Additional proof of Jonson's republican strain may be seen in his apparent approval of tyrannicide: "A tyranne, how great and mighty soever hee may seeme to Cowards and Sluggards; is but one creature, one Animal" (VIII, 598). And a certain indication of Jonson's humanist republicanism is his special emphasis on the counsellors' role in government. Jonson seems to have shared the humanists' belief that they were the only feasible substitutes for philosopher-kings in their time. ${ }^{12}$ In Discoveries he writes that "the good counsellors to princes are the best instruments of a good Age" (VIII, 601) and expresses the belief that it is the Prince's ministers who must govern the realm: "But they are ever good men, that must make good the times: if the men be naught, the times will be such" (VIII, 571). Moreover, Jonson's exalted conception of himself as a poet, expressed both in the Epistle to the Universities and in Discoveries, shows that he too was a humanist who tried to approximate the philosopher-king ideal as a royal counsellor. The sublime idea of the poet Jonson expressed was part of a movement toward a republic of merit and away from a hierarchy of rank. This is the political implication of Jonson's self-aggrandizement:

I could never thinke the study of Wisdome confin'd only to the Philosopher: or of Piety to the Divine: or of State to the Politicke. But that he which can faine a common-wealth (which is the Poet) can governe it with Counsels, strengthen it with Lawes, correct it with Judgements, informe it with Religion, and Morals; is all these. (VIII, 595)

One last proof of the humanist republican tendency in Jonson is his overwhelming sense of the evils of nobles and princes, which he shared with Erasmus and More. Particularly in Discoveries (VIII, 600-04), in the tragedies, and in the Panegyre and coronation entertainments, Jonson conveys his perception that bad princes and nobles are the rule, not the exception. Two quotations may exemplify this view. In the Entertainment at Highgate, Mercury advises James to "triumph ... over the ridiculous pride of other Princes; and for ever live in the love, rather than the feare of your subjects" $(11.272-75)$. In the epigram to Sir Horace Vere (Ep.XCI), Jonson celebrates his friend's "Humanitie, and pietie, which are/As noble in great chiefes, as they are rare."

In addition to their tendency toward republicanism, the fundamentally moralistic emphasis of the humanists also makes up a part of Jonson's political thought. Jonson uses the humanists' conception of the king as God's agent in the same way they did: to restrain the king's freedom of action. ${ }^{13}$ In the Panegyre James learns this about kings: 
That they, by Heaven are placed upon his throne,

To rule like Heaven; and have no more, their owne,

As they are men, then men. (11. 79-81)

In passages in Discoveries that draw on Henry Farnese, Jonson writes that "the strength of Empire is in Religion" (VIII, 600) and emphasizes the need for mercy (VIII, 594, 600); also, using Erasmus' Adagia, he makes the point that only justice and religion "make Kings a kinne to Gods" (VIII, 603). He stresses the fact that God will judge the king both for his own acts and those of his ministers (VIII, 600, 603). The most striking evidence of Jonson's moral emphasis, however, is his insistence that the prince must be a good man to be a good ruler. In Discoveries Jonson writes that "Wise, is rather the Attribute of a Prince, then learned, or good," but he echoes Erasmus in his marginal note: "Sed vere prudens haud concipi posit Princeps, nisi simul et bonus" (VIII, 594). ${ }^{14}$ Jonson's persistent demand that the prince rule "by example, more than sway" (Ep. XXXV), besides revealing his fear of princes' power, illustrates his fundamentally moralistic conception of politics. ${ }^{15}$ The dedication to Cynthia's Revels defines the court as the "fountain of manners"; this image, which Erasmus also uses in the Education of a Christian Prince, ${ }^{16}$ epitomizes Jonson's moralistic humanism - it judges the court as a source of good or bad examples, demanding that the nation's leaders inspire and not infect the rest of the commonwealth. At the end of the play, Cynthia is given this speech, which stresses the ruler's responsibility to set a good example if he wants his subjects to be good:

\footnotetext{
Princes, that would their people should doe well,

Must at themselves begin, as at the head;

For men, by their examples, patterne out

Their imitations, and reguard of laws:
}

A vertuous Court a world to vertue draws. (5.11.169-73)

Two other humanist influences seem to operate in Jonson's political thought. The first, the humanists' debate about the merits of being a detached intellectual and the merits of being an active servant of the state, seems reflected in Jonson's alternation between rejection of and active participation in his society. ${ }^{17}$ In Jonson's anxiety about his roles as satirist and encomiast and his ambivalence toward the court, we can see a version of the problem that vexed early humanists like More and Starkey. The humanist dilemma seems to lie behind Jonson's ambivalence about his role as a satirical playwright, which has received much critical attention, ${ }^{18}$ and is the background of the critical debate about the course of Jonson's dramatic career, in which one group of critics argues that Jonson was alienated from his society and another that he became reconciled to it. ${ }^{19}$

The other humanist influence is the humanists' pacificism and distaste for religious disputes. ${ }^{20}$ The anti-war sentiments expressed so often in Jonson's 
work, ${ }^{21}$ along with his aversion to "Controverters in Divinity" (VIII, 59596), stem from the Erasmian tradition. Like Erasmus, Jonson wanted Christians to be at peace and believed that they should not quarrel over insignificant differences in doctrine: "some errors may be dissimuled with lesse inconvenience, then can be discover'd" (Discoveries, VIII, 596).

As Jonson's Discoveries show, Jonson knew the work of English humanists like More, Chaloner, and Elyot, and of Europeans like Erasmus, Patrizi, Farnese, and Lipsius. His debt to the humanists was enormous. After an examination of their influence on Jonson's royalism, one thing is clear: the idea that Jonson believed in Stuart absolutism is false. The humanist Jonson was a constitutional monarchist in the tradition of More and Starkey.

A review of contemporary political theory in England helps confirm this reading of Jonson's monarchism. We must, however, know where to begin. In his recent Ben Jonson: Public Poet and Private Man, George Parfitt inexplicably and anachronistically examines the background of Jonson's political thought by discussing Filmer's Patriarcha and Harrington's Oceana, even though both works postdate Jonson's death, Filmer's by five years and Harrington's by nineteen. ${ }^{22}$ Parfitt's book, though in some ways a good account of Jonson's political and social ideas, shows how imprecise Jonsonian scholarship has been in treating Jonson's politics. As Parfitt might have found in the Conversations with Drummond or in Discoveries, the political thinker most important in establishing Jonson's political thought is not Filmer or Harrington, but Hooker. Jonson's remark to Drummond that Hooker's Laws was the authoritative work on "church matters" (I, 136) suggests Hooker's germaneness; while focused on Hooker's ecclestiastical rather than political expertise, it indicates Hooker's importance to Jonson in a time when church matters and state matters were not easily distinguished. Hooker's work manifests the truth of Camden's maxim that "Religion and the Commonwealth cannot be parted asunder."23 Furthermore, when one adds to Jonson's comment to Drummond his praise of Hooker in Discoveries, one must see Hooker as the most important English source for his political theory. In his list of English writers, Jonson writes, "Sir Philip Sidney, and Mr. Hooker (in different matter) grew great Masters of wit, and language; and in whom all vigour of Invention, and strength of judgement met" (VIII, 591).

In addition to Jonson's direct comments on Hooker, we have other reasons for focusing on Hooker's Laws as particularly relevant to Jonson's politics. Long regarded as a source of Elizabethan commonplaces, Hooker was, as a political thinker, "incomparably the greatest Englishman of the sixteenth century." 24 Furthermore, he was praised by writers on all sides: Catholics, Anglicans, and Puritans. ${ }^{25}$ Moreover, Hooker and Jonson shared a milieu that suggests Hooker's importance to Jonson's politics. For instance, Camden, Jonson's friend and teacher, urged that the Laws be translated into Latin so that the whole world could read the book. Also, Hooker wrote the Laws while 
serving as a Master of the Temple Church; his book reflects the influence of the Inns of Court, with which Jonson was closely associated. ${ }^{26}$ Lastly, Hooker was greatly admired by Falkland's circle at Great Tew, by "sons of Ben" like Falkland, Hyde, and Morley. John Earle finally made the Latin translation of Hooker during the 1650's. ${ }^{27}$ Hooker's influence, therefore, impinges on Jonson's whole career, from the 1590's to the 1630's.

Despite the fact that Jonson may not have known (unless in manuscript) Book VIII, the most political book in the Laws, Hooker is the most important English political theorist Jonson knew. Jonson's ignorance of Book VIII (published in 1648) may even be irrelevant, for, as Thompson points out, the specifics in Book VIII follow closely from the general principles outlined in Book I. In the opinion of one modern editor of Book VIII, the book was not published in the 1590's because it was too radical for the age; it was published in 1648 because of its constitutionalism, as "part of a campaign to win the King back to a more moderate view of a royal prerogative and the people to a reasonable allegiance to the King." 28

As Houk's opinion indicates, Hooker's real importance in Elizabethan political thought is far different from the importance assigned to him by Tillyard and his followers. Since Tillyard, there have been, in fact, two Hookers, and, as Wilbur Sanders writes, "the Hooker of the scholarly footnotes, the vade-mecum of stock attitudes, has as little relation to the real Hooker as the Elizabethanism he is used to buttress has to the realities of Elizabethan culture." 29 The real Hooker, for example, is traditionally English in believing that monarchy is not the only possible form of government, that other forms of government are possible: "that the Christian world should be ordered by kingly regiment, the law of God doth not anywhere command" (p. 172). ${ }^{30}$ As we have seen, Jonson also expresses this belief in Discoveries (VIII, 598).

Hooker's view of monarchy obviously shows that he did not believe in the divine right of kings. He believed in a monarchy in which the law, not the king, was supreme: "Happier that people whose law is their king in the greatest things, than that whose king is himself their law" (p. 178) ${ }^{31}$ Hooker believed in a mixed monarchy, in which the sovereign is the king in parliament, not the king alone. ${ }^{32}$ As we can see, Hooker's political ideas reinforce the impression derived from our analysis of Jonson's humanistic inheritance: they establish the likelihood of Jonson's constitutional royalism.

Hooker's authority with Jonson on "church matters" also supports the view that Jonson was part of the movement toward religious toleration in England. Hooker, combining opposition to the Puritans with a general attitude of religious toleration, provides another insight into Jonson's opinions, indicating another source of his attitudes. ${ }^{33}$ Jonson's praise of Hooker's friend and pupil Edwin Sandys for his work on religious toleration (VIII, 591; XI, 243) makes it certain that Jonson valued this aspect of Hooker. 


\section{0 / Renaissance and Reformation}

Both Hooker's constitutional monarchism and his tendency toward toleration are important parts of Jonson's political background. But also, the very nature of Hooker's achievement sheds light on Jonson's. Hooker was what Sanders, speaking of Shakespeare, calls a "conservative-radical": his work both looks back to the medieval past and ahead to Whigs like Locke and Algernon Sidney. ${ }^{34}$ In his love of both order and freedom, in his hatred of both rebellion and tyranny, Hooker expressed an attitude that seems to have influenced Jonson, the author of the masques and of Sejanus and Catiline, which portray the reality of autocracy in Tiberius and the threat of it in Julius Caesar.

The special relevance of Hooker's kind of monarchism to Jonson's is indicated by one other piece of evidence. Jonson's admiration for Sidney, with whom he links Hooker in Discoveries as a writer "in whom all vigour of Invention, and strength of judgement met" (VIII, 591), indicates Jonson's endorsement of a monarchism like Hooker's, for Sidney's was very similar. Both Talbert and Caspari have established Sidney's constitutional royalism, which reveals the links between the humanist tradition, the philosophical work of Hooker, and the constitutional thought of men like Sir Thomas Smith. ${ }^{35}$ From both the Arcadia and the Laws of Ecclesiastical Polity, therefore, Jonson inherited a constitutional monarchism. As a humanist and a great admirer of both Sidney and Hooker, Jonson was a royalist in the English tradition.

Although Jonson makes no explicit comments on the English constitutional crisis during his lifetime, we have been able, by studying the influences of the humanists and of Hooker and Sidney, to identify him as a constitutional royalist. If we consider, in addition, the evidence from English public opinion in the sixteenth and seventeenth centuries, then the case for Jonson as a constitutional royalist seems certain.

In his study of sixteenth-century political thought, J.W. Allen points out that the common view of the English polity was that it was a mixed monarchy. The customary view, reflected in Hooker, saw no special grace attached to monarchy, and thus preferred a shared or divided sovereignty. ${ }^{36}$ The general English view of the constitution was best expressed by Sir Thomas Smith, whom Jonson cites in Discoveries in his list of wits (VIII, 591), and whose thought has affinities with Hooker's. ${ }^{37}$ According to Smith, "the most high and absolute power of the realm of England consisteth in Parliament" Parliament being perceived as comprised of the King, Lords, and Commons together. ${ }^{38}$ As one can see, such a constitutional position is far from the divine right of kings. According to Allen, King James's works “were written by a Scot in Scotland and by a man who suffered from the drawback of being himself a King." ${ }^{39}$ James's concept of kingship, of which Lawrence Stone writes "No sensible man could take his claims seriously," 40 reflects Stuart ignorance of English ways. In the words of G.R. Elton, "Stuart divine right 
was revolutionary because it dispensed with the contract and attacked an existing mixed sovereignty."41

The balance in sixteenth-century English political thought was reflected in the crisis of the seventeenth century. According to Allen, "The Royalist party was essentially a constitutional party," even as late as $1642 .{ }^{42}$ Historians of the Jacobean and Caroline crises find striking the similarity between Royalist and Parliamentarian ideas throughout the period. ${ }^{43}$ Both Royalists and Parliamentarians saw themselves as conservatives, upholding the constitution; as Perez Zagorin points out, the "Country" opposition was directed at the Stuarts primarily for being innovators. ${ }^{44}$ The essential agreement between the two sides was symbolized by the unanimity in the 1640 Long Parliament against Charles. Before the events of the next years polarized them, Royalists and Parliamentarians united against the King, who was effectively isolated, with a few extremist cavaliers, from the rest of the nation. ${ }^{45}$ Moreover, even during the Civil War, as the tormented careers of Jonson's "son" Falkland and others showed, many Royalists and Parliamentarians shared fundamental principles.

With this as the background of his political thought, it should now be clearly established that Jonson was a constitutional monarchist. However, because questions may still arise from his masques and from his criticism of the Parliament, we should answer them to remove all doubt.

First of all, it must be said that the extravagant language of the masques, in which some have seen Jonson's endorsement of Stuart absolutism, really represents nothing of the kind. The fact that the masques are an elaborate exercise in laudando praecipere is indicated by the use of similarly extravagant language even by the Stuarts' political enemies, by men like Eliot and Coke. Edmund S. Morgan quotes Eliot's comment of 1628 after his imprisonment in the Tower by Charles:

The goodness of the King is like the glory of the sun, not capable in itself of any obscurity or eclipse, but only by intervenient and dark clouds it may seem to be eclipsed and diminished by us. So by interposition of officers the goodness of the King may be darkened to us.

According to Coke (also in 1628), "In him [the King] is all the confidence we have under God. He is God's lieutenant. Trust him we must." ${ }^{\prime 46}$ Morgan brilliantly summarizes the opponents' attitude:

The Commons did not say, "The king is God's lieutenant, therefore we must do what he wants." Instead, they said, "The king is God's lieutenant, therefore he must want what we want, because we want only what is right." (p. 13)

This attitude is a key to Jonson's use of divine and solar identifications in the masques. Jonson shared with Coke and Eliot, with all contemporary Englishmen, the use of the same political fiction - which, unfortunately, James and 
Charles took for fact, accepting as reality the fantasy of self-sufficiency Jonson used in the masques but derided in his comedies. ${ }^{47}$

On the basis of the following passage, George Parfitt writes that Jonson was no great believer in Parliaments:

Suffrages in Parliament are numbered, not weigh'd: nor can it bee otherwise in those publike Councels, where nothing is so unequall, as the equality: for there, how odde soever mens braines, or wisdomes are, the power is alwayes even, and the same. (VIII, 579)

Why this is not accepted merely as an accurate observation about the weakness inherent in voting, which even a democrat can see, I do not know. Instead, it is cited as evidence of Jonson's animosity toward the institution of Parliament. ${ }^{48}$ The facts seem to indicate, however, that this passage and Epigram XXIV -

There's reason good, that you good lawes should make:

Mens manners ne're were viler, for your sake,

- show only Jonson's awareness of Parliament's defects, not his antagonism toward it. Even if the passage in Discoveries on misjudging the sovereign's actions, glossed "Morbus comitalis," refers to Parliament (VIII, 593; XI, 245), it shows no more than Jonson's knowledge that Parliaments, like princes, have vices. Jonson's friend Martin, a leader of the Parliamentary opposition, had to make a public apology for his castigation of Parliament: Jonson's attack on Parliament's abuses must be seen in this light. ${ }^{49}$ The evidence from Jonson's attitude toward Parliament, like the evidence from his masques, does not conflict with the interpretation of Jonson as a constitutional royalist. Like Hooker, and Sidney, like his closest patrons and friends, Jonson was in the mainstream of English political thought in believing in limited monarchy.

In dealing with the humanists and with Hooker and Smith, we have already indirectly touched on Jonson's classical inheritance. However, because Jonson was such an outstanding classicist, the classical influences on his political thought should be examined separately. As we shall see, Jonson's inheritance from both the Greek and Roman classics provides additional evidence that he was a constitutional monarchist. In fact, many of the classical authors Jonson valued most were prominent in shaping English republican thought. Jonson seems to have played some part in the tradition Hobbes writes of in Leviathan, II, XXIX; Hobbes, who knew Jonson, ${ }^{50}$ writes:

And as to rebellion in particular against monarchy, one of the frequent causes of it is the reading of the books of policy and histories of the ancient Greeks and Romans. ... From the reading, I say, of such books, men have undertaken to kill 
their kings, because the Greek and Latin writers, in their books, and discourses of policy, make it lawful and laudable for any man so to do, provided, before he do it, he call him tyrant. ${ }^{51}$

In Discoveries Jonson calls Aristotle "the greatest Philosopher, the world ever had" (VIII, 640). Such a statement allows the inference that Jonson attached some weight to Aristotle's Politics, which was a source of the contemporary theory of a mixed government by the one, the few, and the many. ${ }^{52}$ Because Aristotle was, with Aquinas, Hooker's most important source, and essential to Smith's standard interpretation of the English constitution, ${ }^{53}$ Aristotle's importance to Jonson must be considered further evidence that Jonson was, in his constitutional monarchism, in the mainstream of English political thought. Aristotle, part of Jonson's medieval inheritance and part of the seventeenth-century attempt to limit the monarchy, is another source of Jonson's "conservatism," which looks both to the past and to the future after the Stuarts.

Jonson's Roman models, Cicero and Horace, also give us insight into his politics. The admiration for Cicero expressed in Discoveries (VIII, 591) and in Catiline, where he is the hero of the republic, suggests Jonson's republican tendencies. ${ }^{54}$ As one of the primary sources of the myth of the Roman republic in seventeenth and eighteenth century England, ${ }^{55}$ Cicero symbolizes one important aspect of Jonson's thought. Because Cicero also was an influence on the mixed government theory, Jonson's admiration for this writerstatesman suggests, again, the qualified nature of his royalism. ${ }^{56}$

Jonson's identification with Horace gives further evidence of this. Knowing Horace's republican past, Jonson portrays his relations with Augustus in such a way as to reveal his own attitude toward monarchs and monarchy. In the ideal, comic world of Poetaster, Horace is able to rebuke Augustus for a gibe against his poverty and be thanked for it:

Thanks, Horace, for thy free, and holsome sharpnesse:

Which pleaseth Caesar more, then servile fawnes.

"A flatterd prince soon turnes the prince of fooles.

And for thy sake, wee'll put no difference more

Betweene the great, and good, for being poore. (5.1.94-8)

In the idealized Rome of Poetaster, Horace can assert to Augustus' face that his soul "is as free, as Caesars" (5.1.90), and Augustus places Vergil on his throne, proclaiming that "Vertue, without presumption, place may take/ Above best Kings, whom onely she should make" (5.2.26-7). In Jonson's fantasy, which seems to express deep personal feelings, kings are made for poets, not poets for kings.

Jonson's idealization of the Augustan age in Poetaster stems from one motivation only: his esteem for it as the time "When wit, and artes were at 
their height in Rome" ("Apologeticall Dialogue,"1. 102). In his play Augustus' primary function is to vindicate poetic merit. Jonson's real view of Augustus as a politician probably can be inferred from his negative treatment of Julius Caesar in Catiline and of Tiberius in Sejanus. ${ }^{57}$ A reader of Suetonius, Jonson could hardly have seen Augustus solely as a genial patron of Horace and Vergil. ${ }^{58}$ Indeed, the play itself expresses Jonson's uneasiness in representing the Augustan age as ideal. In portraying Caesar's ridiculous homicidal rage against his daughter and Ovid, his refusal to hear Horace's plea for clemency $(4.6 .1-16,60-78)$, and his reliance on spies and informers, Jonson reveals his fuller views of Augustus. Jonson's inability to whitewash Augustus even in a comedy where he is primarily a royal patron, not the emperor, along with his treatment of Horace and Vergil as Caesar's equals, suggests that Jonson-Horace was a very independent royalist. He wanted to be a licensed satirist like the Horace of Poetaster, he valued a monarchy that established peace after civil war and promoted the arts, but he remained suspicious of royal power and fantasized that the Horaces and Vergils of his day would effectively rule the realm through their counsel. ${ }^{59}$

The view that for English classicists of the Renaissance and eighteenth century "the Augustan standard would serve," "both the political and literary judgments," is quite misleading ${ }^{60}$ It falsely identifies Augustus as the political ideal in the time. Like the early eighteenth-century writers, Jonson valued the literary achievement of the Augustan age, but chose for his political heroes

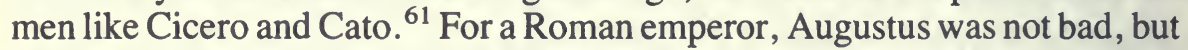
in Poetaster he still is too much like other kings, whose nature Ovid, masked as Jupiter, expresses: "Wee are a King, cotqueane, and we will raigne in our pleasures; and wee will cudgell thee to death, if thou find fault with us" (4.5.93-5).

Besides Cicero and Horace, the other major Roman writer Jonson especially valued was Tacitus. While he deplored the amateur Taciteans of "The New Crie" (Ep. XCII, 1. 15) and Machiavellian Taciteans (ML 1.7.29-33), Jonson esteemed Tacitus highly, as is evident in Epigram $\mathrm{CI}$ and in his conversations with Drummond, where Tacitus is listed as one of the three Romans who "speke best Latine" and described as the historian who "wrott the secrets of the Councill and Senate" (I, 136). These praises, coupled with his poem on Savile's translation (Ep. XCV) and his use of Lipsius' edition of Tacitus for Sejanus, link Jonson to the Tacitean movement in his time, of which his friends Bacon and Camden were a part. ${ }^{62}$

According to Peter Burke, there were four strands in seventeenth-century Tacitism: "admiration for Tacitus as a stylist; as a historian; as a moralist; and, above all, as a master of politics" (p. 151). Jonson expresses all of these. We have already seen evidence of his admiration of Tacitus' style and skill as a historian. The particular value attached to the histories by Taciteans, the 
analysis of causes and hidden motives, ${ }^{63}$ is expressed in Jonson's remark about "secrets" and his focus on "things, the causes, and the men" (1.34) in the poem to Savile. "Ethical Tacitism," which refers both to Tacitus' psychological analysis of character and his moral judgments on them, is evident in Sejanus. Jonson examines closely the link between private vice and public disaster, and, as L.C. Knights points out, shares Tacitus' moralistic tendency to simplify characters into good and evil. ${ }^{64}$

The political significance of Jonson's Tacitism lies in its opposition to autocracy. Burke cites Lipsius and Montaigne for the contemporary view that "the rise of monarchies has made Europe more like Rome under the Emperors" (p. 161), and gives as an example of contemporary application of Tacitus Eliot's speech of 1626 against Buckingham, which compared the favorite to Sejanus. ${ }^{65}$ This speech, in which Jonson's friend Cotton had a part, shows the political import of works like Sejanus. For Englishmen under James and Charles, plays like Sejanus undoubtedly had "uncontrollable associations" to use a term from Soviet censorship of the 1970's. ${ }^{66}$

Tacitus, who, like Cicero, played an important part in establishing the mystique of the Roman republic, certainly influenced Jonson's republican tendencies. Of the two kinds of Tacitism current in Jonson's time, "Tacitismo rosso," disguised republicanism, and "Tacitismo nero," disguised Machiavellianism, ${ }^{67}$ Jonson's is certainly closer to the former. If any further proof of this is needed, it may be found in the direction of his departures from Tacitus' Annals in Sejanus. For example, he takes from Tiberius a valid attack on the servile Senate and gives it to the republican Sabinus. He invents a speech for Silius and therefore makes him more of a republican hero than he is in the Annals. Furthermore, bringing his Tiberius closer to seventeeth-century kings, he makes him a religious hypocrite, changing his source to do so. ${ }^{68}$

The conclusion one must draw from Jonson's use of Tacitus is clear. Jonson's distaste for absolutism and his republican sympathies are reflected in his choice of a Roman historian. G.R. Hibbard is correct: "Other things being equal, it is likely that the dramatist using historical matter will be drawn to the writings of the historian whose general outlook on life has most in common with his own." As Hibbard points out, "Jonson was unique among the major Elizabethan dramatists in being drawn to Tacitus."69

The political import of Jonson's use of Tacitus is also revealed in his use of other Roman writers. Suetonius, his other principal source for Sejanus, for example, was another enemy of absolutism: Jonson, who linked Suetonius to Tacitus in commenting on Suetonius' writing the secrets "of the Cabinet and Courte" (I, 136), undoubtedly derived from the Lives an aversion to unlimited royal power. Seneca, too, may have been an influence on his moderate royalism, for he quotes De Clementia (addressed to Nero) in Discoveries, in direct opposition to Machiavellian counsels of cruelty (VIII, 599-600), and 


\section{6 / Renaissance and Reformation}

Jonson follows the Senecan tradition in his low view of Julius Caesar. ${ }^{70}$ In Catiline, Jonson deviates from his source, Sallust, in order to indict Caesar, to implicate the ambitious dictator-to-be in Catiline's conspiracy. ${ }^{71}$

From Lucan, too, Jonson derived a hatred of Caesar and Caesarism, as is evident in "A Speech out of Lucane" (Ungath. L) which also appears in Sejanus 2.178-185, and in his verses on Tom May's translation (Ungath. XXIX, 11. 9-11).$^{72}$ Furthermore, Jonson's reading of Juvenal undoubtedly led him to detest the corruption of an autocratic state. The nature of Jonson's classical inheritance may be epitomized in a brief list of some of the sources of his Discoveries. From Suetonius and Dion Cassius, Jonson takes his account of the tyrant Caligula; from Suetonius, the sentiment that a prince should shear and not flay his sheep (VIII, 598, 602). From Quintus Curtius on Alexander, Jonson derives his defense of tyrannicide (VIII, 598). Aulus Gellius is the source of the attack on "the great theeves of State" (VIII, 603), which echoes Cato's attack on "fures publici" quoted there. Finally, the encomium of poverty and the poor and the derision of "wealthy Giants" (VIII, 605) Jonson takes from Apuleius. ${ }^{73}$

As L.C. Knights has written, Jonson's "admiration for the old Roman republican virtues is related to, is part of, his liveliest feelings about the present in which he lived." 74 Jonson's classical inheritance links him to English humanists of republican, not courtly, tendency. ${ }^{75}$ The Roman Jonson, more than a counterweight to the Jonson of the masques, establishes the constitutional royalism of Jonson the Englishman.

In his study of Jonson's debt to Machiavelli, The Devil's Disciple, Daniel Boughner evaluates Jonson's use of the Italian's insights into realpolitik in Sejanus and Volpone as well as Jonson's rejection of Machiavellian amorality in Discoveries. While not a wholly persuasive argument for Machiavelli's influence on Jonson, Boughner's book establishes the connection between Jonson and one of the age's greatest political thinkers. However, Boughner's interpretation of the political implications of Machiavelli's influence on Jonson is weakened by his limited knowledge of sixteenth-century English political thought. For example, because he misinterprets the Tudor homily against disobedience as a "declaration of hereditary absolutism" and puts undue emphasis on the self-serving political writings of King James, he distorts Jonson's English royalism into absolutism (pp. 93-4). ${ }^{76}$ Jonson's statement that "the merciful Prince is safe in love, not in feare" is cited as evidence of Jonson's "Monarchic rapture" (p. 145), although the statement seems more directive than encomiastic, and is hardly rapturous. Similarly, "After God, nothing is to be lov'd of man like the Prince" is said to exemplify Jonson's "numinous theory of the principate" (p. 150), even though the next sentence in the passage limits the obligation of love to a prince who serves "the publike good, and common safety" (VIII, 594). Boughner confidently writes of Jonson's horror of tyrannicide (p. 94), ignoring Jonson's explicit defense of it in Discoveries (VIII, 598). 
By bringing a fuller understanding of sixteenth-century political thought to bear on Jonson's debt to Machiavelli, we can evaluate it more accurately than Boughner. Knowing that the English tradition was constitutional royalism, not absolutism, and acknowledging the republican tendencies in Jonson and other humanists, we can see the implications of Jonson's drawing his defense of elected government and praise of the common people from Machiavelli. Discussing the prince who has been elected by "the suffrage of the people," Jonson writes, translating from Machiavelli:

The latter hath no upbraiders; but was rais' $d$ by them, that sought to be defended from oppression: whose end is both the easier, and the honester to satisfie. Beside, while he hath the people to friend, who are a multitude, he hath the lesse feare of the Nobility, who are but few. Nor let the common Proverbe of (Hee that builds on the people, builds on dirt) discredit my opinion: For that hath place, where an amibitious, and private person, for some popular end, trusts in them against the publike Justice, and Magistrate. There they will leave him. But when a Prince governs them, so as they have still need of his Administration (for that is his Art) hee shall ever make, and hold them faithfull. (VIII, 598-99)

Boughner must see this as anomalous: "The monarchist and rabble-hater has momentarily become a democrat by a kind of literary contagion" (p. 145). The truth is that one side of Machiavelli, his classical republicanism, his belief in mixed government, attracted Jonson, a classicist and a citizen of a mixed monarchy. ${ }^{77}$ Machiavelli, frequently associated with Tacitus in Jonson's time, may have been, in his dissection of the ways of princes and his nostalgia for the republic, another source of Jonson's "Tacitismo rosso."78

The most important fact about Jonson's relation to Machiavelli is, of course, Jonson's rejection of Machiavellian amorality in Discoveries, where clemency is opposed to politic cruelty (VIII, 599-600). However, as Felix Raab pointed out, the characteristic English response to Machiavelli was ambivalence. Jonson, like his countrymen, used Machiavelli as "a convenient source, to be cited with approval where appropriate, and reviled when his tenets conflicted too obviously with accepted moral and theological canons." J9 Jonson, opposing Machiavelli's "atheism," as in Volpone 4.1.227 , could yet draw on his ideas to buttress his constitutional monarchism.

Another influence on Jonson's moderate royalism was the native tradition examined by L.C. Knights, which establishes that "Jonson's art is intimately related to the popular tradition of individual and social morality." 80 Jonson, who used the Old English comedy and the morality play in his drama, expresses a moralistic attitude like that expressed in the ballads and in Bunyan: a belief in the basic equality of men under God and an association of finery with folly, pride, and death. ${ }^{81}$ Jonson's belief in the superiority of virtue over birth is part of the popular tradition as well as the humanist tradition. 82

The English tradition in Jonson is manifested in various ways. His close connection to the moralistic medieval writers is evident in the quotations from 
Chaucer, Gower, and Lydgate in The English Grammar, a work of his last years (XI, 201). His use of popular political language may be seen in two passages in Discoveries. Writing of a prince without counsel, he uses one of Caxton's fables in referring to the ruler as "a crowned Lyon" (VIII, 601; XI, 250). In discussing corrupt officers, he writes

The great theeves of a State are lightly the officers of the Crowne; they hang the lesse still; play the Pikes in the Pond; eate whom they list. The Net was never spread for the Hawke or Buzzard that hurt us, but the harmlesse birds, they are good meate. (VIII, 603).

As E.W. Talbert points out, even Jonson's courtly works, his masques, have links with a popular tradition: the instructive pageants of London citizens. ${ }^{83}$

Jonson's connection to the popular tradition can also be seen in his satiric attacks on Puritans and lawyers, which often are misinterpreted as evidence of his elitism. The satire of Puritans is at least in part motivated by Jonson's defense of popular entertainments against Puritan opposition, as is indicated by the poem to Dover (Ungath. XLIII), if not by Bartholomew Fair. Secondly, the satire of lawyers, which Bevington, following Harbage, sees as evidence of Jonson's "patrician" elitism, ${ }^{84}$ stems from a tradition at least as old as Piers Plowman and extending to the present day. In satirizing lawyers, Jonson was at one with the people as with intellectuals like Bacon, Burton, and Greville. ${ }^{85}$

Despite Jonson's intellectual elitism, which did not attribute much intelligence to either the common people or nobles, Jonson was part of the popular English tradition. In fact, Jonson occasionally praised the people's common sense explicitly. Besides the praise of the virtuous poor in Discoveries (VIII, 605 ), there is, as we have seen, the tribute to their fidelity to the prince, which surpasses the nobles'. The passage derived from Machiavelli shows that Jonson made the observation, shared by Shakespeare and Camden, that the common people are disposed to obedience, rarely revolting against established authority. ${ }^{86}$ In Jonson, as in Shakespeare, it is not typically the multitude who are giddy, but the nobles.

As E. B. Partridge points out, Jonson's joining the Company of Tylers and Bricklayers in 1598 indicates that he was not a social climber ${ }^{87}$ From the people, like Shakespeare, Marlowe, and many other great Elizabethan writers, Jonson was also of the people too, in important ways. L.C. Knights' account of his debt to the popular tradition and this brief sketch suggest that Jonson's native Englishness also informs his constitutional royalism.

The influence of English Catholicism on Jonson serves to develop further our understanding of Jonson's royalism. A Catholic from 1598 to 1610, a man who had Catholic friends all his life, Jonson embodied the qualified royalism characteristic of Catholic intellectuals in his time. 
It is difficult to determine precisely all the political concomitants of Jonson's Catholicism, but one thing that his period of Catholicism undoubtedly reinforced was his tendency to see himself as persecuted, as part of a minority defending the traditions of the nation in a corrupt present. At the same time, of course, it doubtless inculcated in him a hatred of the persecution, as a number of references in his works and conversation indicate. One may, for example, read an indictment of the age in his comment to Drummond on the Jesuit Southwell, celebrated in Catholic circles for his courage: "That Southwell was hanged yett so he had written that piece of his ye burning babe he would have been content to destroy many of his" (I, 137) ${ }^{88}$ Without a doubt, Jonson's hatred of spies and informers, expressed in Sejanus and in Epigrams LIX and CI, derives from his bitter experience as a Catholic. Lastly, his remark that "Warner since the Kings comming to England had marrd all his Albions England" (I, 133) conveys his distaste for the vicious antiCatholicism current in England. ${ }^{89}$

It is a reasonable inference that Jonson's loyalty to the Stuarts, despite his objections to many of their policies, stems in part from their partial toleration of Catholics. ${ }^{90}$ Similarly, his unexalted view of the Tudors may have arisen from their persecution of his co-religionists. His references to the Tudors are especially revealing, for they show Jonson's lack of enthusiasm for the Elizabethan establishment. In the Panegyre, Jonson summarizes the formative reign of Henry VIII in these terms:

Where lawes were made to serve the tyran' will;
Where sleeping they could save, and waking kill;
Where acts gave license to impetuous lust
To bury churches, in forgotten dust,
And with their ruines raise the panders bowers:
When publique justice borrow'd all her powers
From private chambers; that could then create
Lawes, judges, counsellors, yea prince and state. ${ }^{91}$ (11.99-106)

Naturally, in his treatment of Elizabeth Jonson allows for more virtues, but the positives are outweighed by the negatives. The elevation of the ideal Queen in the original ending of Every Man Out and in Cynthia's Revels is undercut by the Entertainment at Althorpe (11. 155-86, 261-73), which details the vices of Elizabeth's court (far worse than the follies in Cynthia's Revels) and even derides Elizabeth's favoritism in terms that recall $C R 4 \cdot 5 \cdot 76-81$. Jonson's unexalted view of Elizabeth, which may have resembled his friend Donne's, ${ }^{92}$ is best revealed in the unflattering portrait he gave Drummond:

Queen Elizabeth never saw her self after she became old in a true Glass. They painted her and sometymes would vermilion her nose, she had allwayes about Christmass evens set dice, that threw sixes or five, and she knew not they were 


\section{0 / Renaissance and Reformation}

other, to make her win and esteame her self fortunate. That she had a Membrana on her which made her uncapable of man, though for her delight she tryed many. (I, 141-42)

The independence from the Tudor point of view that Jonson's Catholicism inevitably fostered suggests again the restricted nature of his royalism. In discussing Jonson's Catholicism we should bear in mind the words of a recent student of English Catholics in his age: "The Catholic community ought properly to be considered a branch of the English nonconforming tradition."93 As J.W. Allen has shown, English Catholics and Puritans both agreed that the Tudors had betrayed the cause of religion for the sake of a secular, quasireligious monarchy. ${ }^{94}$ The Catholics stressed the absurdity of entrusting religion to secular princes, whom history had shown to care little about religion or morality. ${ }^{95}$ As Douglas Bush has written, the Jacobean assertion of divine right arose partly as a reaction to the Catholic assault on heretical monarchs. ${ }^{96}$

As an English Catholic, therefore, Jonson was exposed to anti-Tudor and anti-absolutist thought. His Catholicism undoubtedly taught him to suspect royal attempts to use religion for political propaganda and to claim for the Crown a special religious sanction. ${ }^{97}$ When one considers also that Catholic political thinkers like Parsons and Allen stressed popular consent and proclaimed the right of subjects to depose bad rulers, then one must infer that English Catholicism for Jonson could have been a source only of limited royalism. ${ }^{98}$ Kenelm Digby's attempted bargain with Cromwell in the 1650's is but an extreme example of one trend in contemporary English Catholicism - a trend away from a fixed loyalty to the Crown. ${ }^{99}$

In addition to the moderate royalism (with suspicion of the King) that Jonson probably inherited from his Catholic experience, he also may have received from it a strong impetus toward religious toleration. The English Catholics formulated an obviously self-serving endorsement of freedom of conscience that had some influence on the growth of toleration in the country. ${ }^{100}$ Jonson's Catholic experience, coupled with his friendships with many Protestants notable in the movement toward toleration, probably made Jonson relatively tolerant of religious differences. His praise of Edwin Sandys and his endorsement of Hooker's Laws after his reconversion to Anglicanism are, as we have implied, indicative of this view.

Jonson's Catholicism, one source of his attachment to the Stuarts, adds to our knowledge of his royalism. His experience as an outsider, as a member of a persecuted minority, undoubtedly lies behind his nervous expressions of loyalty, his defensiveness about his place in court. At the same time, his Catholicism reinforced his constitutional monarchist inheritance, making him wary of royal abuses of power and suspicious of royal uses of religion. The world of Sejanus is, in part, the world of an English Catholic in the early seventeenth century. 
A survey of the various parts of Jonson's political background establishes that constitutional monarchism was the mainstream of English political thought in Jonson's time and that Jonson belonged in that mainstream. A study of the social and political thought of his age indicates that Jonson's works are the products of a critical royalism, of moral and political demands distinctly Christian, classical, and English.

Haddonfield, New Jersey

Notes

1 A History of Political Thought in the Sixteenth Century (1928; rev. 1957; New York: Barnes and Noble, 1960), pp. 269, 268, 270. See also English Political Thought 1603-1644 (1938; rpt. Hamden, Conn.: Archon, 1967), pp. 101, 410-11, 482-84.

2 “'Present Occasions' and the Shaping of Ben Jonson's Masques," ELH, 45 (1978), 212.

3 C.H. Herford and Percy and Evelyn Simpson, ed., Ben Jonson (Oxford: Clarendon Press, 1925-52), $\mathrm{X}, 427$; Ernest William Talbert, "The Interpretation of Jonson's Courtly Spectacles," PMLA, 61 (1946), 460, 462 , 468; John J. Enck, Jonson and the Comic Truth (Madison: Univ. of Wisconsin Press, 1957), pp. 68-69; John C. Meagher, Method and Meaning in Jonson's Masques (Notre Dame: Univ. of Notre Dame Press, 1966), p. 181. Representative treatments of Jonson as a believer in paternalistic monarchy include Daniel C. Boughner, The Devil's Disciple: Ben Jonson's Debt to Machiavelli (New York: Philosophical Library, 1968), pp. 94, 145, 150-51; K.W. Evans, "Sejanus and the Ideal Prince Tradition," SEL, 11 (1971), 249-64; Dale B.J. Randall, Jonson's Gypsies Unmasked: Background and Theme of the Gypsies Metamorphos'd (Durham: Duke Univ. Press, 1975), pp. 163-65; George Parfitt, Ben Jonson: Public Poet and Private Man (New York: Barnes and Noble, 1977), pp. 147-49.

4 "The Divine Right of Kings," Studies in Tudor and Stuart Politics and Government (Cambridge: Cambridge Univ. Press, 1974), II, 197. See also 209-11.

5 My understanding of English humanism derives primarily from Arthur B. Ferguson, The Articulate Citizen and the English Renaissance (Durham: Duke Univ. Press, 1965) and Fritz Caspari, Humanism and the Social Order in Tudor England (1954; New York: Teachers College Press, 1968).

6 Herford and Simpson, VIII, 593, 605. All quotations from Jonson are from this edition, hereafter noted as HS. In Eastward Ho 3.3.25-35, Captain Seagull's report describes some Utopian uses of gold in Virginia.

7 On the humanists see Ferguson, pp. 146, 160-99, 201-2, 212 and Ernest William Talbert, The Problem of Order (Chapel Hill: Univ. of North Carolina Press, 1962), pp. 14-18, 82-5.

8 On the humanist background of this idea see Ferguson, pp. 225-27; J.G.A. Pocock, The Machiavellian Moment (Princeton: Princeton Univ. Press, 1975), p. 339; Christopher Morris, Political Thought in England: Tyndale to Hooker (London: Oxford Univ. Press, 1953), pp. 60, 64.

9 The Complete Works of St. Thomas More, ed. Edward Surtz, S.J. and J. H. Hexter (New Haven: Yale Univ. Press, 1965), IV, 157.

10 On the humanists see Ferguson, pp. 172-73.

11 See Ferguson, pp. 200-43; Caspari, pp. 69, 74, 76,392-4; Talbert, The Problem of Order, p. 18; Morris, p. 21; Pocock, p. 339; Jack H. Hexter, Reappraisals in History (Evanston: Northwestern Univ. Press, 1962), pp. 69-70; Alfred Harbage, Shakespeare and the Rival Traditions (1952; Bloomington: Indiana Univ. Press, 1970), pp. 261-62.

12 See Ferguson, p. 212.

13 On the humanists see Paul Archambault, "The Analogy of the 'Body' in Renaissance Political Literature," Bibliotheque d'Humanisme et Renaissance, 29 (1967), 21-53 and Felix Raab, The English Face of Machiavelli (London: Routledge and Kegan Paul, 1964), p. 22.

14 See $H S$ XI, 245. 


\section{2 / Renaissance and Reformation}

15 For other uses of this idea see Panegyre, 11. 125-27; Und. LXIV; The Haddington Masque, 11. 184-93; Oberon, 11. 258-64; The King's Entertainment at Welbeck, 11. 320-22.

16 Trans. Lester K. Born (New York: Columbia Univ. Press, 1936), pp. 175-76.

17 On the humanists see Ferguson, pp. 167-68, 176-80.

18 See Alvin Kernan, The Cankered Muse (New Haven: Yale Univ. Press, 1959), pp. 156-91; Jonas A. Barish, Ben Jonson and the Language of Prose Comedy (Cambridge: Harvard Univ. Press, 1960), pp. 87-9; Robert C. Jones, "The Satirist's Retirement in Jonson's 'Apologetical Dialogue," $E L H, 34$ (1967), 447-67; Gabriele Bernhard Jackson, Vision and Judgment in Ben Jonson's Drama (New Haven: Yale Univ. Press, 1968), pp. 15-19, 30, 32, 42-3, 50-1; Brian Gibbons, Jacobean City Comedy (Cambridge: Harvard Univ. Press, 1968), pp. 18, 81, 153, 168, 186-96; W. David Kay, "The Shaping of Ben Jonson's Career: A Reexamination of Facts and Problems," MP, 67 (1970), 235; J. A. Bryant, The Compassionate Satirist (Athens: Univ. of Georgia Press, 1973), pp. 1-19; Jonas A. Barish, "Jonson and the Loathed Stage," A Celebration of Ben Jonson, ed. William Blissett et al. (Toronto and Buffalo: Univ. of Toronto Press, 1973), pp. 27-53.

19 Outstanding representatives of the "hard" view are Jackson; Robert Ornstein, "Shakespearian and Jonsonian Comedy,"ShS, 22 (1969), 43-6; Alan Dessen, Jonson's Moral Comedy (Evanston; Northwestern Univ. Press, 1971); Edward B. Partridge, The Broken Compass (New York: Columbia Univ. Press, 1958). The "soft" view is presented by Barish, Ben Jonson and "Feasting and Judging in Jonsonian Comedy," Renaissance Drama, 5 (1972), 3-35; Richard Levin, “"No Laughing Matter': Some New Readings of The Alchemist," SLI, 6 (1973), 85-99; Harry Levin, "Two Magian Comedies: 'The Tempest' and 'The Alchemist," "ShS, 22 (1969), 47-58; Bryant; Ian Donaldson, "Jonson and the Moralists," Two Renaissance Mythmakers, ed. Alvin Kernan (Baltimore: Johns Hopkins Univ. Press, 1977), pp. 146-64; Lester A. Beaurline, Jonson and Elizabethan Comedy (San Marino: Huntington Library, 1978), pp. 1-34.

20 See Caspari, p. 63 and Robert P. Adams, The Better Part of Valor (Seattle: Univ. of Washington Press, 1962).

21 See, for example, Panegyre, 11. 60-1; The Gypsies Metamorphos'd, 11. 321-22; Time Vindicated, 11. 426-27; Prince Henry's Barriers, 1. 204; Discoveries, VIII, 602; ML 2·6・109-10; Und. XLIII, 11. 197-212.

22 Pp. 149-59.

23 Quoted from Fred J. Levy, Tudor Historical Thought (San Marino: Huntington Library, 1967), p. 281.

24 Allen, A History of Political Thought in the Sixteenth Century, p. 184.

25 H.R. Trevor-Roper, "The Good and the Great Works of Richard Hooker," NYR, 24, No. 19 (1977), 48.

26 W. Speed Hill, "The Evolution of Hooker's Laws of Ecclesiastical Polity," Studies in Richard Hooker, ed. W. Speed Hill (Cleveland: Case Western Reserve Univ. Press, 1972), pp. 117-58; also, W.D.J. Cargill Thompson, "The Philosopher of the 'Politic' Society," Studies, p. 46.

27 Trevor-Roper, pp. 53-4.

28 Raymond Aaron Houk, ed. Hooker's Ecclesiastical Polity Book VIII (New York: Columbia Univ. Press, 1931), p. 117. See also pp. 96-99, Thompson, p. 23, and L.C. Knights, Public Voices (Totowa, N.J.: Rowman and Littlefield, 1972), p. 54. All quotes from Hooker are from Houk's edition.

29 The Dramatist and the Received Idea (Cambridge: Cambridge Univ. Press, 1968), p. 321.

30 See Allen, A History, pp. 191-93; Trevor-Roper, 50; Morris, pp. 183-84.

31 See Thompson, p. 45; Allen, A History, pp. 193-95; Talbert, The Problem of Order, p. 52; Sanders, pp. 147-49, 367; Morris, pp. 184-85.

32 See Morris, p. 188; Thomson, pp. 23, 46-50; Talbert, The Problem of Order, pp. 43, 50-2.

33 On Hooker's importance in the growth of religious toleration, see Allen, A History, p. 241; Knights, Public Voices, pp. 57-9; Trevor-Roper, 51-55; Wilbur K. Jordan, The Development of Religious Toleration in England (1936; rpt. Gloucester, Mass.: Peter Smith, 1965), I, 222-32.

34 Sanders, p. 325; See Morris, pp. 196-98 and Knights, Public Voices, p. 57.

35 The Problem of Order, pp. 89-117; Caspari, pp. 295-331.

36 A History, pp. 122, 127, 262.

37 Christopher Hill in Intellectual Origins of the English Revolution (Oxford: Clarendon Press, 1965), pp. 
270-71 points out that there were eleven editions of Smith's De Republica Anglorum between 1583 and 1640.

38 On Smith see Allen, A History, pp. 262-68; Talbert, The Problem of Order, pp. 21-64; Morris, p. 81; L. Alston, ed., De Republica Anglorum (Cambridge: Cambridge Univ. Press, 1906), pp. XIII-LIII; Mary Dewar, Sir Thomas Smith (Univ. of London: Athlone Press, 1964), pp. 110-14.

39 A History, p. 252.

40 The Causes of the English Revolution 1529-1642 (London: Routlege and Kegan Paul, 1972), p. 94.

41 Studies in Tudor and Stuart Politics and Government, II, 213.

42 English Political Thought, p. 411; see also pp. 12, 376, 391, 406-7, 410.

43 See Allen, English Political Thought, pp. 33, 44; Elton, 155-63, Margaret Judson, The Crisis of the Constitution (New Brunswick: Rutgers Univ. Press, 1949), pp. 1-106.

44 The Court and the Country (New York: Atheneum, 1970), p. 83. See also Knights, Public Voices, pp. 61,129 n. 17.

45 See Elton, pp. 167-68; Stone, pp. 136-43.

46 “The Great Political Fiction," NYR, 25, No. 3 (1978), 13-14.

47 On this fantasy and absolutism see Gabriele Bernhard Jackson, "Structural Interplay in Ben Jonson's Drama," in Two Renaissance Mythmakers, pp. 117-19 and Sanders, p. 188.

My emphasis on the masques' didacticism parallels the readings of Barish, Ben Jonson, p. 244 and Ernest William Talbert, "The Interpretation of Jonson's Courtly Spectacles," pp. 454-73, although Talbert's article is marred by the assertion that Jonson believed in divine right (pp. 460, 462, 468). I disagree with John Meagher's association of the masques with divine right in Method and Meaning in Jonson's Masques, p. 181, and I seek to add a historical dimension missing in Stephen Orgel's The Jonsonian Masque (Cambridge: Harvard Univ. Press, 1967) and The Illusion of Power (Berkeley: Univ. of California Press, 1975).

48 p. 29; see also Evans, p. 250.

49 On Martin see Philip J. Finkelpearl, John Marston of the Middle Temple (Cambridge: Harvard Univ. Press, 1969), pp. 67-8.

50 See Aubrey's Brief Lives, ed. Oliver Lawson Dick (Ann Arbor: Univ. of Michigan Press, 1957), pp. $150,157$.

51 Quoted from Zera S. Fink, The Classical Republicans (Evanston: Northwestern Univ. Press, 1962), 2nd ed., p. 1. On this tradition see Fink; Hill, p. 276; Clifford Chalmers Huffman, Coriolanus in Context (Lewisburg: Bucknell Univ. Press, 1971), pp. 30, 54-60, 65, 223-29; Paul Cantor, Shakespeare's Rome (Ithaca: Cornell Univ. Press, 1976), p. 17.

52 Fink, pp. 2-3; Pocock, p. 355.

53 On Hooker see Thompson, p. 21; Talbert, The Problem of Order, pp. 44, 51, 52, 56. On Smith see Talbert, The Problem of Order, pp. 21-4, 35, 36, 40.

54 The critical debate about Cicero's character does not affect my interpretation of Cicero's importance to Jonson's politics. Whatever one's opinion of Cicero's morality, it is clear that Jonson's sympathies are with the republic against the Catilinian rebels and Caesar. In my positive reading of Cicero in Catiline, I agree with Barish, Ben Jonson, p. 48; Jackson, Vision and Judgment, pp. 37, 151; Dessen, p. 138. I disagree with those who see Cicero as disturbingly Machiavellian: Robert Ornstein, The Moral Vision of Jacobean Tragedy (Madison: Univ. of Wisconsin Press, 1960), pp. 102-4; Anselm Schlosser, "Ben Jonson's Roman Plays," Kwartnalnik Neofilologuiczny, 8 (1961), 146-50; Calvin G. Thayer, Ben Jonson: Studies in the Plays (Norman: Univ. of Oklahoma Press, 1963), pp. 118, 125-27; Robert E. Knoll, Ben Jonson's Plays: An Introduction (Lincoln: Univ. of Nebraska Press, 1964), p. 139; Angela G. Dorenkamp, "Jonson's Catiline: History as the Trying Faculty," SP, 67 (1970), 214-15; W.F. Bolton and Jane F. Gardner, ed., Catiline (Lincoln: Univ. of Nebraska Press, 1973), p. XVI; Larry S. Champion, Tragic Patterns in Jacobean and Caroline Drama (Knoxville: Univ. of Tennessee Press, 1977), pp. 84-5. The problematic nature of political action in Catiline is well examined by Schlosser; by M.J.C. Echeruo, "The Conscience of Politics in Jonson's Catiline," SEL, 6 (1966), 341-56; and by Michael J. Warren, "Ben Jonson's Catiline: The Problem of Cicero," Yearbook of English Studies, 3 (1973), 55-73.

55 Addison Ward, "The Tory View of Roman History," SEL, 4 (1964), 413-56. 


\section{4 / Renaissance and Reformation}

56 On Cicero's place in political thought see Fink, pp. 5-8, 10; Pocock, p. 371; also, David Stockton, Cicero: A Political Biography (London: Oxford Univ. Press, 1971), pp. 343-45.

57 Explicit links between Tiberius and Augustus are made in Sejanus 1.459-73; 3.484-87, 503-7. Howard D. Weinbrot, in Augustus Caesar in "Augustan" England (Princeton: Princeton Univ. Press, 1978) sees Jonson's representation of Tiberius as involving a criticism of Augustus too: a use of the idea that "the ruler who destroys liberty yet rules well himself is responsible for the bad rulers after him" (p. 44).

58 Huffman, pp. 228-29, points out that the Elizabethans knew that Cicero was a victim of the Triumvirate.

59 In Discoveries he mentions, apparently approvingly, that Augustus wanted to make Horace "a secretary of Estate" (VIII, 643).

60 Patrick Cruttwell, The Shakespearean Moment (London: Chatto and Windus, 1954), p. 210. For this view see also Thayer, p. 119.

61 On the English Augustans see Ward, 413-56 and James William Johnson, The Formation of English Neo-Classical Thought (Princeton: Princeton Univ. Press, 1967), pp. 17-18, 63-4.

62 On Tacitism see Mary F. Tenney, "Tacitus in the Politics of Early Stuart England," Classical Journal, 37 (1941), 151-63 and Peter Burke, "Tacitism," Tacitus, ed. T.A. Dorey (New York: Basic Books, 1969), pp. 149-71.

63 Burke, pp. 153-55.

64 Public Voices, p. 47n.

65 See also Kenneth C. Schellhase, Tacitus in Renaissance Political Thought (Chicago: Univ, of Chicago Press, 1976), pp. 163-64.

66 Lev Lifshitz Losev, "What It Means to Be Censored," $N Y R, 25$, No. 11 (1978), 47. The fact that Jonson in Discoveries (VIII, 601) uses the term "Sejanus" to describe contemporary favorites confirms the point.

67 Burke, pp. 162-67, Tenney, pp. 152-54.

68 On the changes see Daniel C. Boughner, "Jonson's Use of Lipsius in Sejanus," MLN, 73 (1958), 253; "Juvenal, Horace, and Sejanus," MLN, 75 (1960), 549; The Devil's Disciple, pp. 96-7; Jonas A. Barish, ed., Sejanus (New Haven: Yale Univ. Press, 1965), pp. 10-15.

69 "Goodness and Greatness: An Essay on the Tragedies of Ben Jonson and George Chapman," Renaissance and Modern Studies, 11 (1967), 19, 20. See also E.B. Partridge, "Jonson's Large and Unique View of Life," The Elizabethan Theatre IV, ed. G.R. Hibbard (Hamden, Conn.: Shoe String Press, 1974), p. 154. Boughner's refusal to accept the Tacitean influence on Jonson's politics stems from his "Elizabethan World Picture" conception of English political thought ( $M L N, 73$ [1958], 248; Devil's Disciple, pp. 93-4).

70 On the Senecan tradition see David Bevington, Tudor Drama and Politics (Cambridge: Harvard Univ. Press, 1968), p. 248.

71 On Jonson's changes see Ellen M.T. Duffy, "Jonson's Debt to Renaissance Scholarship in Sejanus and Catiline," MLR, 42 (1947), 25; Joseph Allen Bryant, Jr., "Catiline and the Nature of Jonson's Tragic Fable," Ben Jonson: A Collection of Critical Essays, ed. Jonas A. Barish (Englewood Cliffs: Prentice-Hall, 1963), pp. 151-52; Dorenkamp, p. 213.

72 On Lucan in England see William Blissett, "Lucan's Caesar and the Elizabethan Villain," SP, 53 (1956), 571-75 and Hill, p. 150.

73 See $H S$ XI, 248, 251, 252, 254.

74 Public Voices, p. 47.

75 On the two groups see Caspari, pp. 392-94.

76 For the proper reading of the homily and James's works, see Allen, A History of Political Thought, pp. $131-33,252$.

77 On Machiavelli see Fink, pp. 10-19 and Pocock, pp. 189-90, 195, 243.

78 On Machiavelli and Tacitus see Burke, pp. 162-67 and Pocock, pp. 351-53.

79 The English Face of Machiavelli, pp. 100-1, 86. 
80 Drama and Society, p. 180; see also pp. 179-227. On the English tradition see also Charles R. Baskervill, English Elements in Jonson's Early Comedy (1911; rpt. New York: Gordian Press, 1967), pp. 1-33 and Dessen, Jonson's Moral Comedy.

81 Knights, Drama and Society, pp. 190, 192.

82 Hill, pp. 266-68, sees this idea having revolutionary implications in the 1640's.

83 “The Interpretation of Jonson's Courtly Spectacles," pp. 454-73.

84 See pp. 265, 273, 278, 287, 288, 300. On Jonson and lawyers see Bertil Johansson, Law and Lawyers in Elizabethan England (Lund: Almquist and Wiksell, 1967), pp. 8, 49-50.

85 On the intellectuals see Allen, English Political Thought, p. 91.

86 Sanders, p. 333 deals with the Elizabethans' qualified trust in the people's common sense. On Camden see F. Smith Fussner, The Historical Revolution (London: Routledge and Kegan Paul, 1962), p. 244.

87 The Elizabethan Theatre IV, p. 149.

88 On Southwell's reputation see David Mathew, Catholicism in England, 3rd ed. (London: Eyre and Spottiswode, 1955), p. 47 and Gerald R. Cragg, Freedom and Authority: A Study of English Thought in the Early Seventeenth Century (Philadelphia: Westminster Press, 1975), p. 215.

89 I have seen a microfilm of William Warner, A Continuance of Albions England (1606). Book 15 contains outrageously bigoted anti-Catholic propaganda, undoubtedly triggered by the Gunpowder Plot.

90 On the Stuarts and Catholics see Mathew, p. 77 and Martin J. Havran, The Catholics in Caroline England (Stanford: Stanford Univ. Press, 1962), pp. 24, 53.

91 Jonson's attitude toward Henry's spoliation of the Church was shared by his Protestant friends of the Society of Antiquaries and by some Puritans. See Philip Styles, "Politics and Historical Research in the Early Seventeenth Century," English Historical Scholarship in the Sixteenth and Seventeenth Centuries, ed. Levi Fox (London: Oxford Univ. Press, 1956), p. 65.

92 Jonson's editors comment, somewhat naively, on Jonson's knowledge of Donne's Metempsychosis, which in one version identified Elizabeth as a heretic $(\mathrm{I}, 136,158)$.

93 John Bossy, The English Catholic Community 1570-1850 (New York: Oxford Univ. Press, 1976), p. 7. In becoming a Catholic under Elizabeth, Jonson was a rebel like his father, a Protestant minister under Mary.

94 A History of Political Thought, pp. 133, 173, 222. See also Lawrence Stone, The Crisis of the Aristocracy 1558-1641 (Oxford: Clarendon Press, 1965), p. 729 on the Anglican establishment.

95 Allen, A History of Political Thought, pp. 203-4, 208; Raab, p. 60. See Volpone 4.1.22-7 for Jonson's attitude toward Machiavelli's and Bodin's erastianism.

96 English Literature in the Earlier Seventeenth Century 1600-1660, 2nd ed. (Oxford: Oxford Univ. Press, 1962), pp. 247-48.

97 "There is nothing with some Princes sacred above their Majesty; or prophane, but what violates their Scepters" (Discoveries, VIII, 600-1).

98 On Parsons and Allen see Allen, A History of Political Thought, pp. 260-62; Morris, pp. 133-35; Robert Ornstein, A Kingdom for a Stage: The Achievement of Shakespeare's History Plays (Cambridge: Harvard Univ. Press, 1972), pp. 24-6.

99 See Bossy, pp. 61-8.

100 Allen, A History of Political Thought, pp. 208-9; English Political Thought, pp. 209-10; Morris, pp. 140-42. 